\title{
Anti-Cripto Mab inhibit tumour growth and overcome MDR in a human leukaemia MDR cell line by inhibition of Akt and activation of JNK/SAPK and bad death pathways
}

\author{
XF Hu', J Li', E Yang', S Vandervalk' and PX Xing*,I \\ 'Cancer Immunotherapy Laboratory, Burnet Institute Incorporating Austin Research Institute, Heidelberg, Australia
}

\begin{abstract}
Doxorubicin (DOX) selection of CCRF-CEM leukaemia cell line resulted in multidrug resistance (MDR) CEM/A7R cell line, which overexpresses MDR, I coded P-glycoprotein (Pgp). Here, we report for the first time that oncoprotein Cripto, a founding member of epidermal growth factor-Cripto-FRL, I-Criptic family is overexpressed in the CEM/A7R cells, and anti-Cripto monoclonal antibodies (Mab) inhibited CEM/A7R cell growth both in vitro and in an established xenograft tumour in severe combined immunodeficiency mice. Cripto Mab synergistically enhanced sensitivity of the MDR cells to Pgp substrates epirubicin (EPI), daunorubicin (DAU) and non-Pgp substrates nucleoside analogue cytosine arabinoside (AraC). In particular, the combination of anti-Cripto Mab at less than $50 \%$ of inhibition concentrations with noncytotoxic concentrations of EPI or DAU inhibited more than 90\% of CEM/A7R cell growth. Cripto Mab slightly inhibited Pgp expression, and had little effect on Pgp function, indicating that a mechanism independent of Pgp was involved in overcoming MDR. We demonstrated that anti-Cripto Mab-induced CEM/A7R cell apoptosis, which was associated with an enhanced activity of the c-Jun $\mathrm{N}$-terminal kinase/stress-activated protein kinase and inhibition of Akt phosphorylation, resulting in an activation of mitochondrial apoptosis pathway as evidenced by dephosphorylation of Bad at Serl 36, Bcl-2 at Ser70 and a cleaved caspase-9.

British Journal of Cancer (2007) 96, 918-927. doi:I0.1038/sj.bjc.660364I www.bjcancer.com
\end{abstract}

Published online 6 March 2007

(C) 2007 Cancer Research UK

Keywords: Cripto Mab; MDR; P-glycoprotein; apoptosis; signalling transduction pathways

Despite advances made over the last 30 years, most acute leukaemia remains difficult to cure owing to the development of multidrug resistance (MDR) (Abd El-Ghaffar et al, 2006; Biscardi et al, 2006). The most well-characterised MDR gene product in relapsed acute leukaemia is P-glycoprotein (Pgp) encoded by MDR1 gene (Abd El-Ghaffar et al, 2006). P-glycoprotein, an ATP-binding protein, functions as an energy-dependent efflux pump resulting in a decreased accumulation of several structurally unrelated drugs including anthracyclines such as doxorubicin (DOX), epirubicin (EPI) and daunorubicin (DAU) and vinca alkaloids such as vinblastine and vincristine as well as epipodophyllotoxins leading to MDR phenotype (Hayes and Wolf, 1990). A number of reagents such as a calcium channel blocker verapamil (Vp), immunosuppressor cyclosporin A (CyA) and its nonimmunosuppressive derivative PSC833 overcame MDR by inhibition of Pgp function (Hu et al, 1990). However, the acquisition of Pgp-mediated MDR during chemotherapy remains poorly understood, and MDR cannot be fully overcome at this stage. A MDR variant CEM/A7R cell line, developed by DOX selection of T-cell lymphoblastic leukaemia CCRF-CEM cell line (Zalcberg et al, 1994), has been successfully used as a model to study the molecular mechanisms underlying

*Correspondence: Professor PX Xing; E-mail: px.xing@burnet.edu.au Received 4 December 2006; revised 24 January 2007; accepted 24 January 2007; published online 6 March 2007 regulation of drug resistance. A rapid upregulation of MDR1 gene in CEM/A7R cell line was induced by anthracyclines and its analogues (Hu et al, 1995, 1999b), and prevented by CyA and its analogue PSC 833 ( $\mathrm{Hu}$ et al, 1996). These results represent the clinical development of Pgp-mediated drug resistance during chemotherapy (Hu et al, 1999a). Although Pgp expression plays a significant role in DOX-induced MDR phenotype, accumulated evidence indicated that additional molecular events besides MDR1 were involved (Watts et al, 2001). Recently oncoprotein Cripto, the founding member of the epidermal growth factor-Cripto-FRL1Criptic (EGF-CFC) family, was also demonstrated to be an important factor in mediating drug resistance (Normanno et al, 2004). We have found that Cripto is upregulated in Pgp-positive CEM/A7R cells. Cripto was first identified and sequenced from a teratocarcinoma cDNA expressing library (Ciccodicola et al, 1989), and is overexpressed in most cancers, implicating its role in tumorigenesis and progression (Saloman et al, 2000).

Both Cripto and MDR1 have been demonstrated as new target genes of $\beta$-catenin (Yamada et al, 2000; Morkel et al, 2003), a key mediator of Wnt signalling pathway. Upregulation of MDR1 and accumulation of $\beta$-catenin have been observed in chemically induced rat and human liver adenomas and adenocarcinomas (Yamada et al, 1999). It is more likely that chemically induced intracellular accumulation of $\beta$-catenin leads to its nuclear translocation and binding to T-cell factor and lymphoid enhancer factor transcription factors, which transactivated MDR1 and 
Cripto along with other Wnt target genes (Seidensticker and Behrens, 2000). This may explain why DOX selection of Pgpmediated MDR phenotype in the CEM/A7R cells leads to simultaneous induction of Cripto expression.

Most chemotherapeutic agents induce tumour cells to undergo a final apoptosis pathway (Fisher, 1994). The defects in the apoptotic pathway represent an important mechanism for the development of chemo-resistance (Minn et al, 1995). Cripto possesses an $\mathrm{N}$-terminal signal peptide, a unique EGF-like motif, a cysteine-rich CFC domain and a short hydrophobic carboxy terminus, which is essential for membrane anchorage by a glycosylphosphatidylinositol (GPI) moiety (Saloman et al, 2000). The EGF-like region of Cripto is involved in activation of c-Src (Bianco et al, 2003), ras/raf/ MAPK (Kannan et al, 1997) and PI3k/Akt/GSK-3 $\beta$ (Ebert et al, 1999) mediated cell proliferation and cell survival signalling pathways. Constitutive activation of PI3K/Akt pathway promotes MDR phenotype in breast cancer (Clark et al, 2002), prostate cancer (Lee et al, 2004) and acute myeloid leukaemia (AML) (Grandage et al, 2005). These observations suggest that Cripto-activated PI3K/ Akt pathway in CEM/A7R cells not only stimulates tumour growth but also induces MDR phenotype through interruption of apoptosis pathways activated by chemotherapeutics. In addition to drug efflux, Pgp overexpression in the CEM/A7R cells also renders cells a cross-resistance to caspase-dependent apoptosis stimulated by cytotoxics and apoptotic stimulus such as Fas ligand (Smyth et al, 1998; Johnstone et al, 1999). These results suggest that tumour cells may use both Cripto and Pgp protein to escape cell death, induced by chemotherapeutic drugs.

Cripto has been identified as a therapeutic target (Adkins et al, 2003; Xing et al, 2004), and the EGF-like region has been regarded as a suitable immunotherapeutic intervention point ( $\mathrm{Hu}$ and Xing, 2005). Two monoclonal antibodies (Mab) $\mathrm{C} 4$ and $\mathrm{C} 13$ have been generated against a Cripto 17-mer peptide, corresponding to the 'EGF-like' motif of Cripto, and have shown effective inhibition of PI3K/Akt pathway and activation of c-Jun N-terminal kinase/stressactivated protein kinase (JNK/SAPK) pathways in colon cancer cells (Xing et al, 2004). In this paper, we are aiming to examine whether the Mab to Cripto could overcome the Pgp-mediated MDR and the signalling transduction pathways interrupted by the Mab. Here, we report that Mab C4 and C13 overcame MDR and inhibited tumour growth of the MDR CEM/A7R cells by inhibition of Akt and activation of JNK/SAPK and mitochondrial apoptotic pathway, demonstrating a new strategy for overcoming Pgp-mediated MDR.

\section{MATERIALS AND METHODS}

\section{Cell lines and cytotoxic drugs}

CEM/A7R is a variant of the CEM/A7 cell line, derived by stepwise selection in increasing concentrations of DOX from a drugsensitive CCRF-CEM parental cell line (Zalcberg et al, 1994), originally developed from a patient with a T-cell lymphoblastic leukaemia (Foley et al, 1965). CEM/A7R line was established by growing the CEM/A7 cells in the absence of DOX for more than 2 years before subcloned in 96-well plates by a limited dilution technique (Hu et al, 1995). Daunorubicin, EPI and cytosine arabinoside (AraC) were obtained from Pharmacia \& Upjohn Pty Limited (Perth, Australia). Verapamil was purchased from Knoll Pty Limited (NSW, Australia). Rh123 was obtained from Sigma (Australia). The CEM/A7R and CCRF-CEM cells were cultured in RPMI 1640 containing $10 \%$ heat-inactivated FCS at $37^{\circ} \mathrm{C}$ in a $5 \%$ $\mathrm{CO}_{2}$ humidified incubator.

\section{Cripto Mab}

Production and characterisation of anti-Cripto EGF-like region Mab C4, C13 have been recently described (Xing et al, 2004).
Briefly, a 17-mer peptide from the EGF-like region amino acids 97-113 (CPPSFYGRNCEHDVRKE) of Cripto was synthesised using an Applied Bio-systems Model 430A automated peptide synthesiser (Foster City, CA, USA) as immunogen. Murine myeloma NS1 cells were fused with spleen cells from Lewis female rats that were immunised three times. First immunization was injected intraperitoneally by $100 \mu \mathrm{g}$ Cripto 17 -mer conjugated to keyhole limpet haemocyanin $(\mathrm{KLH})$; and emulsified in complete Freund's adjuvant. After 4 weeks, a second injection of Cripto 17-mer-KLH with incomplete Freund's adjuvant, and 3 days later, a third injection was given without adjuvant. The supernatants of hybridomas were tested by enzyme-linked immunosorbent assay and immunohistochemistry for their activity and specificity. C4 and C13 Mab were further selected by cell growth assays, and purified from ascites by Sephacryl S300 HR gel filtration after 50\% saturated ammonium sulphate precipitation. The subclasses of the Mab were determined using anti-rat immunoglobulin subclass antibodies (ICN, Irvine, CA, USA).

\section{Cell proliferation assays}

$\left[{ }^{3} \mathrm{H}\right]$-thymidine incorporation assay was performed as previously described (Hu et al, 1990). Briefly, $5 \times 10^{4}$ well $^{-1}$ of CEM/A7R or parental CCRF-CEM cells were cultured for $48 \mathrm{~h}$ at $37^{\circ} \mathrm{C}$ in $5 \% \mathrm{CO}_{2}$ with varying concentrations of Cripto Mabs and chemotherapeutic agents DAU, EPI or AraC. The cells were pulsed with $\left[{ }^{3} \mathrm{H}\right]-$ thymidine (final concentration $1 \mu \mathrm{ci} \mathrm{m}^{-1}$ ) for $4 \mathrm{~h}$ and then harvested onto glass filter papers using an automated cell harvester and radioactivity was measured by TopCount (Perkin-Elmer, Boston, MA, USA). All assays were performed in triplicate and the results were expressed as percentage of $\left[{ }^{3} \mathrm{H}\right]$-thymidine incorporation in the treated group to control (medium only) (Xing et al, 2004). Inhibition of cell growth by Mab equals the percentage of thymidine incorporation of control minus that of treated samples. The results obtained from the assay are comparable from cell growth inhibition assay by using the trypan blue dye exclusion method (Hu et al, 1990; Xing et al, 2004).

\section{Tumour eradication induced by Mab in SCID mice}

Severe combined immuno deficiency (SCID) mice (female, 10-12 weeks of age) were obtained from the Animal Resources Centre, Western Australia, and maintained under specific-pathogen-free conditions for the studies. All animal experiments were approved by Animal Ethics Committee, Austin Health, Australia, and were carried out in accordance with the standards required by the Guidelines for the Welfare of Animals in Experimental Neoplasia (UKCCCR guidelines). The SCID mice were inoculated subcutaneously with CEM/A7R cells $\left(2 \times 10^{7}\right)$. To examine antitumour efficacy of the Cripto Mab on an established tumour in SCID mice, treatment was not started until the tumours size had reached an average size of $100 \mathrm{~mm}^{3}$. C13 Mab ( $0.5 \mathrm{mg}$ per mouse) was administrated intraperitoneally on day 6 , then followed by $0.25 \mathrm{mg}$ C13 twice a week for 3 weeks. Tumours were measured at 2-4 days intervals with a caliper, and tumour size was calculated (length $\times$ width $\times$ height) as described previously (Xing et al, 2004).

\section{Flow cytometry analysis}

Annexin- $V$ binding assay Antibody-induced apoptosis was examined by Annexin $\mathrm{V}$ and propidium iodide (PI) dual staining to detect early apoptotic cells (Vermes et al, 1995). Cells $\left(2 \times 10^{5}\right)$ were incubated with or without $25 \mu \mathrm{g} \mathrm{ml}^{-1}$ of Cripto Mab for $4 \mathrm{~h}$ at $37^{\circ} \mathrm{C}$ in a humidified chamber containing $5 \% \mathrm{CO}_{2}$. The Annexin binding assay was performed using the ApoTarget ${ }^{\mathrm{Tm}}$ Annexin-V fluorescein isothiocyanate (FITC) Apoptosis kit (Biosource, CA, USA). The kit is designed to detect apoptotic cells by flow 
cytometry and examined with a FACScan flow cytometer (Becton Dickinson, Franklin Lakes, NJ, USA).

Cripto and Pgp expression Cells $\left(5 \times 10^{5}\right)$ were incubated with $10 \mu \mathrm{g} \mathrm{ml}^{-1}$ of $\mathrm{C} 13$ or PE-conjugated UIC2 (Colter) at room temperature for $15 \mathrm{~min}$. Nonspecific rat immunoglobulin (Ig)M and murine Mab IgG2a (Chemicon, CA, USA) were used as control for Cripto or Pgp expression, respectively. After three washes the cells were directly analysed for Pgp expression. For Cripto expression, the cells were further incubated with a fluoresceinconjugated sheep anti-rat antibody (Chemicon) at $1: 80$ dilution. Mean channel fluorescence (MCF) was recorded and the expression of Pgp, Cripto was shown as the ratios of the arithmetic MCF of UIC2 or C13 relative to the control antibodies (Hu et al, 1999a).

Rh123 accumulation Rh123 is a fluorescence dye that can be taken up by the cells and pumped out by the Pgp pump. Rh123 accumulation in cells is a sensitive and selective measure of the transport function of Pgp, and can be detected by flow cytometry. Briefly, $5 \times 10^{5}$ cells were incubated with or without $25 \mu \mathrm{g} \mathrm{ml}^{-1}$ Cripto Mab C13, C4 or $10 \mu \mathrm{m} \mathrm{Vp}$ for $3 \mathrm{~h}$, respectively. The cells were washed and the fluorescence was measured after the addition of Rh123 at $200 \mathrm{ng} \mathrm{ml}^{-1}$ to the culture medium in the presence or absence of Mab or $10 \mu \mathrm{m} \mathrm{Vp}$. The cells were then incubated in the dark at $37^{\circ} \mathrm{C}$ for $1.5 \mathrm{~h}$. Rh123 fluorescence was measured through a 530 DF 30-nm filter. The results were expressed as the ratios of MCF in the presence or absence of $\mathrm{Vp}$ or Mab (referred to as Rh123 ratio) (Hu et al, 1999a). An increase in Pgp function by Mab was defined as a change in the Rh123 ratio of treated and untreated cells.

\section{Western blot}

Cells $\left(5 \times 10^{6}\right)$ were treated with Mab C4 for various times in the presence or absence of AraC for 3 or $6 \mathrm{~h}$. The cells were harvested, and washed with ice cold PBS, then lysed and sonicated in $0.5 \mathrm{ml}$ lysis buffer containing $20 \mathrm{~mm}$ Tris (pH 7.5), $150 \mathrm{~mm} \mathrm{NaCl}, 1 \mathrm{~mm}$ EDTA, $1 \mathrm{~mm}$ EGTA, 1\% Triton X-100, $2.5 \mathrm{~mm}$ sodium pyrophosphate, $1 \mathrm{~mm} \beta$-glycerolphosphate, $1 \mathrm{~mm}$ sodium orthovanadate $\left(\mathrm{Na}_{3} \mathrm{VO}_{4}\right), 1 \mu \mathrm{g} \mathrm{ml}^{-1}$ leupeptin and $1 \mathrm{~mm}$ phenylmethyl sulfonyl fluoride. The lysed samples were separated by 12.5 or $7.5 \%$ (for Pgp only) SDS-PAGE and transferred onto a polyvinylidene difluoride membrane (PVDF) (Amersham Pharmacia Biotech, Piscataway, NJ, USA). The blots were blocked with $5 \%$ no-fat dry milk in Trisbuffered saline buffer with $0.1 \%$ Tween-20 at room temperature for $1 \mathrm{~h}$ and probed with appropriate dilution of anti-Cripto Mab C13 or MDR1 (G-1) (Santa, Cruz, sc-13131), or cell signalling antibodies (New England Biolabs) including anti-phospho-Akt at Ser473 (\#9271), anti-Phospho Bcl-2 at Ser 70 (\#2871), anti-Bcl-XL (\#2762), anti-Bad (\#9292), anti-Phospho-Bad at Ser112 (\# 9191), anti-Phospho-Bad at Ser136 (\#9295) and anti-cleaved caspase 9 at Asp330 (\#9501) antibodies. The proteins in the PVDF membranes were visualised using chemiluminescence reagent (Perkin-Elmer) after adding horseradish peroxidase-labelled secondary antibodies.

\section{JNK/SAPK assay}

The JNK/SAPK activity was measured using JNK/SAPK assay kit (New England Biolabs) as described previously (Xing et al, 2004). Briefly, a recombinant fusion protein c-Jun residue 1-89 and glutathione $S$-transferase (GST-c-Jun) were used as the substrate for activated JNK. The supernatant of cell lysate was incubated with immobilised GST-c-Jun fusion protein overnight at $4{ }^{\circ} \mathrm{C}$ to precipitate activated JNK. Kinase reaction was carried out in vitro at $30^{\circ} \mathrm{C}$ for $30 \mathrm{~min}$ in kinase reaction buffer $(25 \mathrm{~mm}$ Tris $-\mathrm{HCl}(\mathrm{pH}$ 7.5), $5 \mathrm{~mm} \quad \beta$-glycerolphosphate, $2 \mathrm{~mm}$ dithiothreitol, $0.1 \mathrm{~mm}$ sodium orthovanadate and $10 \mathrm{mM} \mathrm{MgCl}_{2}$ ) containing $100 \mu \mathrm{M}$ ATP. Phosphorylation of GST-c-Jun on Ser-63 was analysed by immunoblotting using anti-phospho-specific c-Jun (Ser-63).

\section{Statistical analyses}

Two-way analysis of variance (ANOVA), GraphPad Prism Version 4.0 (GraphPad Software Inc., San Diego, CA, USA) was used to analyse the experiment results expressed as mean \pm s.d. The Mann-Whitney nonparametric $U$-test was used to compare the tumour sizes in groups of mice treated with Mab and PBS, respectively. $P<0.05$ was considered to be significantly different (Slinker, 1998).

\section{RESULTS}

\section{Cripto expression and drug resistance}

To determine whether DOX selection of MDR CEM/A7R cells upregulated not only Pgp but also Cripto, Western blot analysis was performed using cell lysates of CEM/A7R and CCRF-CEM cells and probed by Mab to Pgp and anti-Cripto Mab C13. As shown in Figure 1A, MDR CEM/A7R cells overexpressed Pgp (170 kDa), whereas drug-sensitive cell line CCRF-CEM did not express Pgp. In contrast, though both cell lines expressed Cripto, CEM/A7R expressed higher level of Cripto than CCRF-CEM (Figure 1A). Flow cytometric analysis using PE-conjugated Pgp Mab UIC2 showed that ratios of MCF of UIC2 $v s$ control IgG2a were 1.0 (8.8/8.9), 3.2 (34.5/10.7) in CCRF-CEM (Figure 1B) and CEM/A7R, (Figure 1C) respectively, implicating a threefold increase of Pgp expression in the CEM/A7R cells compared to parental CCRF-CEM cells. Cripto expression measured by $\mathrm{C} 13$ binding in flow cytometry analysis showed the ratios of Cripto expression were 2.7 (32.1/12.7) in CCRF-CEM (Figure 1D) and $4.6(80.6 / 17.5)$ in CEM/A7R (Figure 1E) respectively, demonstrating 1.7-fold increase of Cripto expression in the CEM/A7R compared to the CCRF-CEM cells.

The Pgp-positive CEM/A7R cells were extremely resistant to EPI compared with the Pgp-negative CCRF-CEM cells. CEM/A7R cells showed 900-fold increase of resistance to EPI and 18.3-fold increase of resistance to DAU than its parental CCRF-CEM cells when compared at $\mathrm{IC}_{50}$ levels $(0.9 / 0.001)$ for EPI (Figure $1 \mathrm{~F}$ ) and $\left(0.22 / 0.012\right.$ of $\left.\mathrm{IC}_{50} \mathrm{~s}\right)$ for DAU (Figure $1 \mathrm{G}$ ) in $\left[{ }^{3} \mathrm{H}\right]$-thymidine incorporation assay, respectively.

\section{Inhibition of cell proliferation by Cripto Mab}

Anti-Cripto Mab C13 and C4 inhibited cell growth of both CEM/ A7R and CCRF-CEM in a dose-dependent manner by the $\left[{ }^{3} \mathrm{H}\right]-$ thymidine incorporation assay. However, the MDR CEM/A7R cells were more sensitive to inhibition effects of $\mathrm{C} 13$ and C4 than CCRFCEM cells. C13 at $6.25,12.5$ and $25 \mu \mathrm{g} \mathrm{ml}^{-1}$ inhibited 32.3, 74.1 and $93.2 \%$ of $\left[{ }^{3} \mathrm{H}\right]$-thymidine incorporation in CEM/A7R in contrast to $0,25.2$ and $50.7 \%$ of inhibition in CCRF-CEM, respectively (Figure 2A). The $\mathrm{IC}_{50}$ levels of $\mathrm{C} 4$ and $\mathrm{C} 13$ were 5.5 and $8.25 \mu \mathrm{g} \mathrm{ml}^{-1}$ in the CEM/A7R cells and 18.8 and $25 \mu \mathrm{g} \mathrm{ml}^{-1}$ in the CCRF-CEM cells. Therefore, compared to CCRF-CEM cells, CEM/A7R cells were three times more sensitive to antitumour activity of Cripto Mab (Figure 2A). This could be due to the difference in the levels of Cripto expression in the two cell lines (Figure 1A, D and E).

\section{Inhibition of MDR CEM/A7R tumour growth in SCID mice}

The anti-MDR tumour effect of Cripto Mab was further investigated in MDR CEM/A7R xenograft model in SCID mice (Figure 2B). The SCID mice with established tumours (average size $\left.101 \pm 17 \mathrm{~mm}^{3}\right)$ were treated with $\mathrm{C} 13(0.5 \mathrm{mg}$ per mouse) on day 6 , followed by six injections of $0.25 \mathrm{mg}$ (total of $2.0 \mathrm{mg}$ per mouse) as indicated in Figure 2B. The tumour size was reduced significantly in the C13-treated group $\left(300 \mathrm{~mm}^{3}\right)$ compared with untreated control $\left(1480 \mathrm{~mm}^{3}, n=6 ; P<0.05\right)$, and $80 \%$ of reduced tumour size at day 26, 6 days after last $\mathrm{C} 13$ treatment, indicating 
A
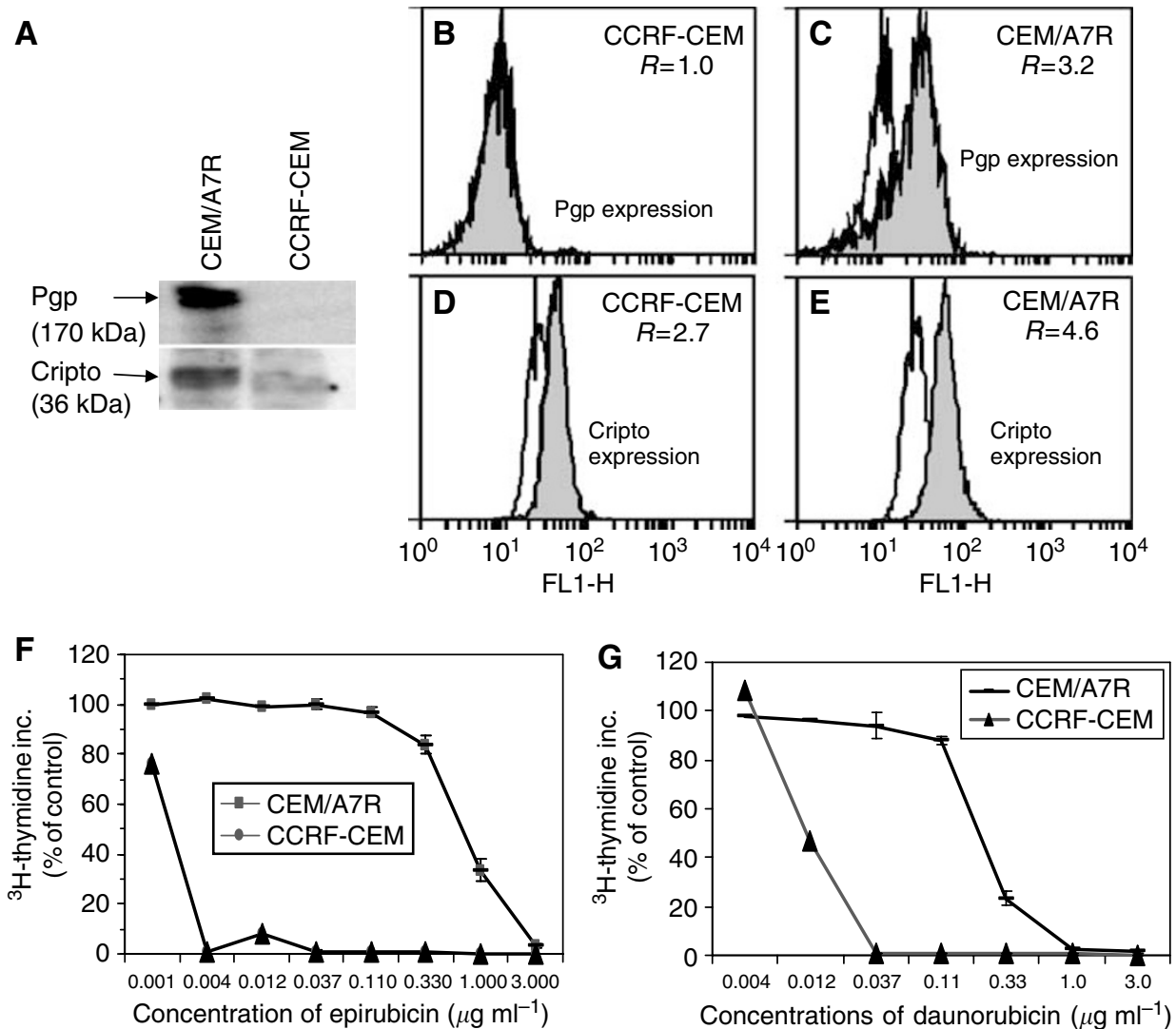

Figure I P-glycoprotein, Cripto expression and association with drug sensitivity in CEM/A7R and parental CCRF-CEM cells. (A) Western blot analysis of Cripto and Pgp expression in the CEM/A7R and CCRF-CEM cells using anti-Cripto Mab CI 3 and Mab to I040- I 280 amino acid of human Pgp. (B and C) P-glycoprotein expression measured by flow cytometric analysis using PE-conjugated UIC2 (solid histogram) compared to an IgG2a (open histogram) and Pgp levels were expressed as the ratio of MCF of UIC2 vs a lg $\mathrm{G}_{2 a}$ control in CCRF-CEM and CEM/A7R. (D and E) Cripto expression was measured by flow cytometry using CI3 (solid histogram) compared to an IgM control (open histogram) in CCRF-CEM and CEM/A7R. Cripto levels were expressed as the ratio (R) of the MCF of $\mathrm{Cl} 3$ vs the IgM control. (F and $\mathbf{G})$ Percentage of control in $\left[{ }^{3} \mathrm{H}\right]$ thymidine incorporation of CEM/A7R and CCRF-CEM in the presence of increasing concentrations of EPI and DAU for $48 \mathrm{~h}$. Points are means of triplicate experiments. Error bars represent the s.d. in triplicate experiments.

the inhibitory effects of anti-Cripto Mab were durable, and may be of value in the treatment of drug resistant leukaemia (Figure 2B).

\section{Apoptosis induced by Cripto Mab}

The binding of Annexin-V-FITC conjugates to cells permits differentiation of apoptotic cells from nonapoptotic cells. Flow cytometry analysis demonstrated 5.9, 44.9 and $12.1 \%$ of Annexin V-FITC and PI-double stained cells after $4 \mathrm{~h}$ incubation of CEM/ A7R cells with medium (Figure 3A) only, C4 (Figure 3B) and C13 (Figure 3C). In contrast, there were $4.7 \%$ in medium (Figure 3D), $17.1 \%$ and $9.6 \%$ in $\mathrm{C} 4$ (Figure 3E) and $\mathrm{C} 13$ (Figure 3F) of Annexin V-FITC and PI-positive CCRF-CEM cells, respectively. The results indicated that the anti-Cripto Mab-induced higher proportions of apoptosis in CEM/A7R (Figure 3B and C) than CCRF-CEM cells (Figure 3E and F).

\section{Cripto Mab sensitise MDR cells to Pgp substrate EPI and DAU}

To determine the effect of anti-Cripto Mab on enhancing cytotoxicity of EPI or DAU, a range of concentrations of each reagent was used on cell growth inhibition of CEM/A7R cells. Mab $\mathrm{C} 13$ inhibited $14.8,60.2$ and $74.7 \%$ of $\left[{ }^{3} \mathrm{H}\right]$-thymidine incorporation at concentrations of $3.13,6.25$ and $12.50 \mu \mathrm{g} \mathrm{ml}^{-1}$. As shown in Figure $4 \mathrm{~A}$, the addition of $3.1 \mu \mathrm{g} \mathrm{ml}^{-1}$ of $\mathrm{C} 13$ to the culture containing noncytotoxic concentrations of $0.11,0.33$ and $1.0 \mu \mathrm{g} \mathrm{ml}^{-1}$ EPI inhibited $40.4,73.5$ and $86.2 \%$ of $\left[{ }^{3} \mathrm{H}\right.$ ]-thymidine incorporation. Combined use of $3.1 \mu \mathrm{g} \mathrm{ml}^{-1} \mathrm{C} 13$ with $0.037,0.11$ and $0.33 \mu \mathrm{g} \mathrm{ml}^{-1}$ DAU showed growth inhibition of 50.2, 81.7 and $91.2 \%$, respectively, compared to $11.8,41.5,67.5$ inhibited by DAU alone (Figure 4B). Similar results were seen with $6.25 \mu \mathrm{g} \mathrm{ml}^{-1} \mathrm{C} 13$ in combination with EPI or DAU (Figure $4 \mathrm{~A}$ and B). It is obvious that combined use of the anti-Cripto $\mathrm{Mab}$ and cytotoxic drugs significantly enhanced the inhibitory effect of each reagent compared with use alone. Importantly, more than $90 \%$ of $\left[{ }^{3} \mathrm{H}\right]-$ thymidine incorporation inhibition can be achieved by combined use of $\mathrm{C} 13$ at less than $50 \%$ of inhibition concentrations with noncytotoxic concentrations of EPI or DAU (Figure 4A and B). Two-way ANOVA analysis demonstrated that there were synergistic effects in most combinations of $\mathrm{C} 13$ and EPI or DAU $(P<0.05$ or $P<0.01, P<0.001$ as indicated by ${ }^{*}, * *, * *$ in Figure $4 \mathrm{~A}$ and $\left.\mathrm{B}\right)$. These results indicate that Cripto Mab $\mathrm{C} 13$ at less than $\mathrm{IC}_{50}$ concentrations could reverse drug resistance in the MDR CEM/ A7R cells. Similar results were observed in the combined use of C4 and EPI or DAU (data not shown).

\section{Cripto Mab sensitise MDR cells to non-Pgp substrate AraC}

Non-Pgp substrate AraC at noncytotoxic concentrations of 0.0015 , 0.003 and $0.005 \mu \mathrm{g} \mathrm{ml}^{-1}\left(\leqslant \mathrm{IC}_{50}\right)$ generated $1.4,5.7$ and $39.7 \%$ of inhibition of $\left[{ }^{3} \mathrm{H}\right]$-thymidine incorporation respectively in CEM/ A7R cells. C4 alone inhibited $0,18.2$ and $82.9 \%$ of $\left[{ }^{3} \mathrm{H}\right]$-thymidine 

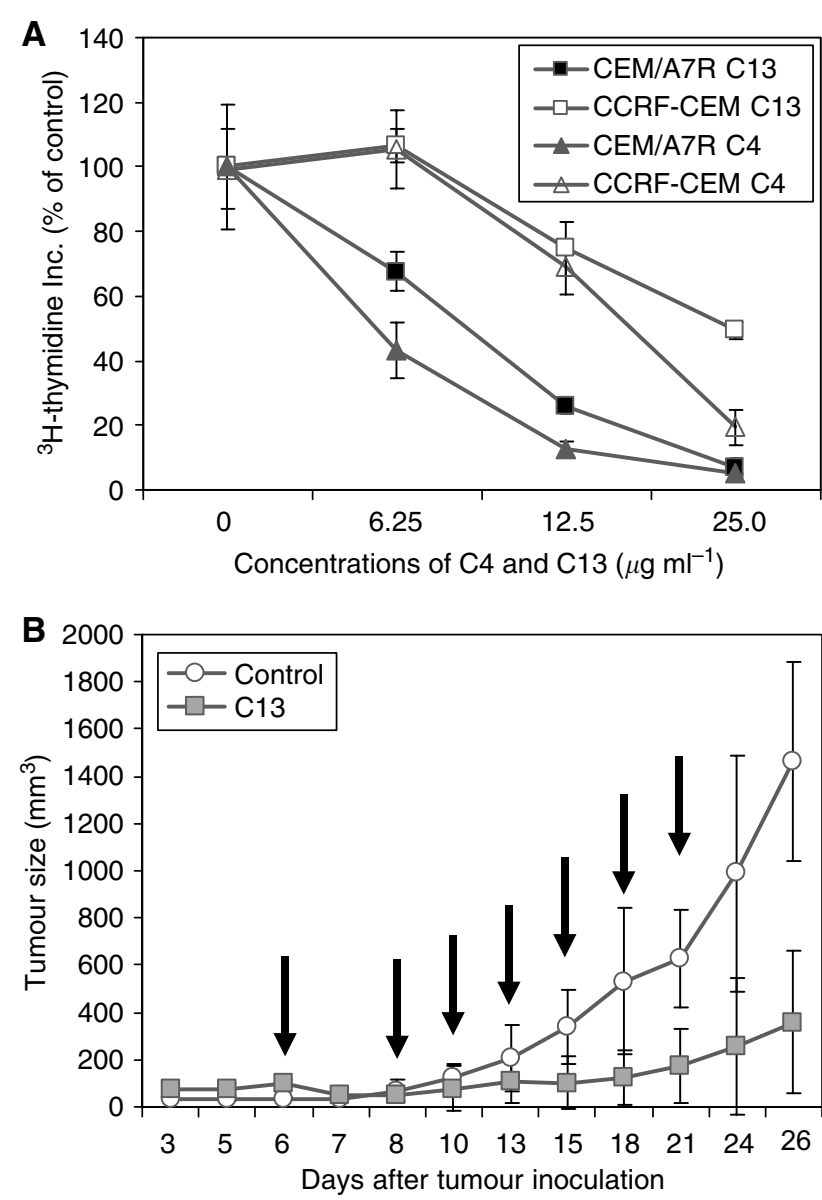

Figure 2 Inhibition of cell growth of CEM/A7R by anti-Cripto Mabs in vitro and in vivo. (A) Percentage of control in $\left[{ }^{3} \mathrm{H}\right]$ thymidine incorporation of CEM/A7R and CCRF-CEM in the presence of $\mathrm{C} 4$ and $\mathrm{Cl} 3$ for $48 \mathrm{~h}$. Points are means of triplicate experiments. Error bars represent s.d. in triplicate experiments. (B) In vivo antitumour effect of anti-Cripto Mab $\mathrm{Cl} 3$ on established tumour of CEM/A7R xenografts in SCID mice. The SCID mice were inoculated s.c. with $2 \times 10^{7}$ CEM/A7R MDR cells, and treated with $0.5 \mathrm{mg} \mathrm{Cl} 3$ on day 6 and $0.25 \mathrm{mg}$ afterward (arrows) when the average size of the tumours was $100 \mathrm{~mm}^{3}$. Points show means and bars are s.d. of tumour size.

incorporation of CEM/A7R at concentrations of 1.0, 2.5 and $10.0 \mu \mathrm{g} \mathrm{ml}^{-1}$, respectively. The addition of $2.5 \mu \mathrm{g} \mathrm{ml}^{-1} \mathrm{C} 4$ to the tissue culture medium containing $0.0015,0.003$ and $0.005 \mu \mathrm{g} \mathrm{ml}^{-1}$ of AraC generated 37.1, 44.7 and $76.9 \%$ of inhibition of $\left[{ }^{3} \mathrm{H}\right]-$ thymidine incorporation, respectively, in the CEM/A7R cells. A $95.2 \%$ of inhibition was obtained by combined use of $10.0 \mu \mathrm{g} \mathrm{ml}^{-1}$ $\mathrm{C} 4$ and $0.005 \mu \mathrm{g} \mathrm{ml}^{-1}$ AraC (Figure 4C). The results indicated that combined use of the anti-Cripto $\mathrm{Mab}$ and AraC significantly enhanced the inhibitory effect than when they were used alone. Two-way ANOVA analysis demonstrated the combined use of C4 and AraC had a synergistic effects $(P<0.05$ or $P<0.01$, as indicated by ${ }^{*}$, or ${ }^{* *}$ in Figure $4 \mathrm{C}$ ). A synergistic effect was also observed in combination of $\mathrm{C} 13$ or $\mathrm{C} 4$ and AraC in CCRF-CEM cells (data not shown).

\section{Rh123 accumulation by Cripto Mab}

The effects of $\mathrm{C} 13$ on Pgp function were determined by comparison with Pgp modulator Vp on intracellular accumulation of Rh123 fluorescence, a sensitive assay for assessment of Pgp function and the results were expressed as ratios of MCF of Rh123 (Hu et al, 1999a). P-glycoprotein modulator Vp at $10 \mu \mathrm{M}$ increased
Rh123 accumulation in CEM/A7R cells by 2.9 -fold (751/259) (Figure 5C) and had no significant effect on the Pgp-negative CCRF-CEM cells (ration 0.94; 1275/1361) (Figure 5A). The data demonstrated that overexpression of Pgp resulted in threefold decrease (2.90/0.90) of Rh123 accumulation in CEM/A7R than CCRF-CEM cells (Figure 1A and C). Figure 5B and 5D shows the changes of Rh123 accumulation in the CEM/A7R cells following $3 \mathrm{~h}$ incubation with C13. Verapamil increased accumulation of Rh123 at similar extent (ratio 2.87:526/183) (Figure 5B) compared to the CEM/A7R cells (ratio 2.90) (Figure 5C). In contrast, C13 alone had little effect on intracellular Rh123 in the CEM/A7R cells after C13 treatment (ratio $0.97: 181 / 186$ ) (Figures 5D). Similar results were seen in the cells treated with $\mathrm{C} 4$ (data not shown). The results indicated that $\mathrm{C} 13$ and $\mathrm{C} 4$ had little effect on inhibition of Pgp function, suggesting the effects of anti-Cripto Mab on the overcoming drug resistance were Pgp independent.

\section{The effect of Cripto Mab and AraC on regulation of Pgp expression}

It has been previously shown that Pgp substrates anthracyclines and its analogues as well as non-Pgp substrate AraC differentially upregulated Pgp expression in the CEM/A7R cells (Hu et al, 1995, 1999b) and in blast cells from AML, respectively (Hu et al, 1999a). In the present study, the regulation of Pgp expression by $\mathrm{C} 4$ or $\mathrm{AraC}$ and the combined use of $\mathrm{C} 4$ and $\mathrm{AraC}$ were analysed by Western blot and flow cytometry. CEM/A7R cells were treated for $6 \mathrm{~h}$ with $10 \mu \mathrm{g} \mathrm{ml}^{-1} \mathrm{C} 4,0.02 \mu \mathrm{g} \mathrm{ml}^{-1} \mathrm{AraC}$ individually or in combination. Western blot analysis showed $\mathrm{C} 4$ slightly decreased Pgp expression in CEM/A7R cells in the presence or absence of AraC (Figure 5E). P-glycoprotein expression had no significant changes in ratios tested by flow cytometry following the above treatment (data not shown).

\section{Activation of SAPK/JNK signalling pathway}

Signalling events involved in the anti-MDR tumour effects of Cripto Mab on MDR CEM/A7R cells were examined by comparison of $\mathrm{C} 4$ and non-Pgp substrate $\mathrm{AraC}$ and their combination on the activation of stress-activated protein kinase/ c-Jun N-terminal kinase (SAPK/JNK) proapoptotic pathways. Stress-activated protein kinase/c-Jun N-terminal kinase is activated by multiple forms of stress including UV, radiation, inflammatory cytokines, and has been implicated as a mediator of stress-induced apoptosis (Davis, 2000). A sustained activation of SAPK/JNK led to cancer cell apoptosis (Xia et al, 1995). Activation of SAPK/JNK proapoptotic pathways was examined by using JNK kinase assay in the cell lysates from CEM/A7R cells treated with $10 \mu \mathrm{g} \mathrm{ml}^{-1} \mathrm{C} 4,0.02 \mu \mathrm{g} \mathrm{ml}^{-1}$ AraC for 3 and $6 \mathrm{~h}$ or in combination (Figure 6A). c-Jun N-terminal kinase activity was increased at $3 \mathrm{~h}$ of incubation of CEM/A7R cells with $10 \mu \mathrm{g} \mathrm{ml}^{-1} \mathrm{C} 4$ compared to control, and remained at the elevated level by $6 \mathrm{~h}$. In contrast, $0.02 \mu \mathrm{g} \mathrm{ml}^{-1}$ AraC significantly activated JNK with higher level than $\mathrm{C} 4$ at $3 \mathrm{~h}$ incubation, and declined at $6 \mathrm{~h}$. Combined use of $\mathrm{C} 4$ and AraC-enhanced JNK activity compared to $\mathrm{C} 4$ and AraC alone by $6 \mathrm{~h}$ (Figure 6A). The results indicated that $\mathrm{C} 4$ and AraC alone activated JNK activity and combination treatment showed a sustained enhancement of JNK activity by 3 and 6 h (Figure 5A).

\section{Inhibition of Akt by Cripto Mab}

Tumorigenesis of Cripto is related to its activation of c-Src, MAPK and PI3K/Akt pathways (Kannan et al, 1997; Ebert et al, 1999; Bianco et al, 2003). Akt is activated by Cripto through phosphorylation of Ser473 at the $\mathrm{COOH}$-terminus to promote cell survival and proliferation (Ebert et al, 1999). Moreover, JNKdependent apoptotic signalling pathway can be blocked by activation of survival signalling Akt (Xia et al, 1995). An inhibition 
A

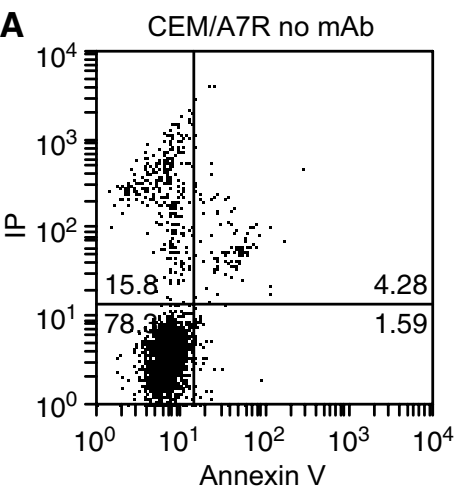

D

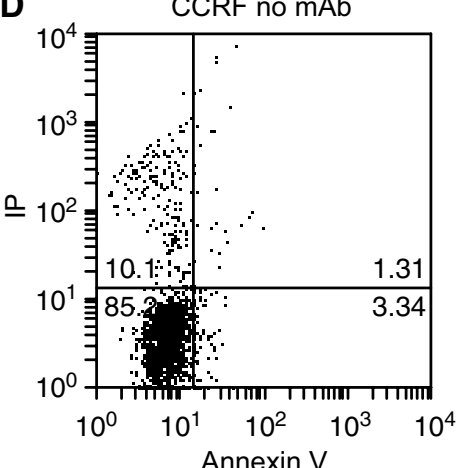

B

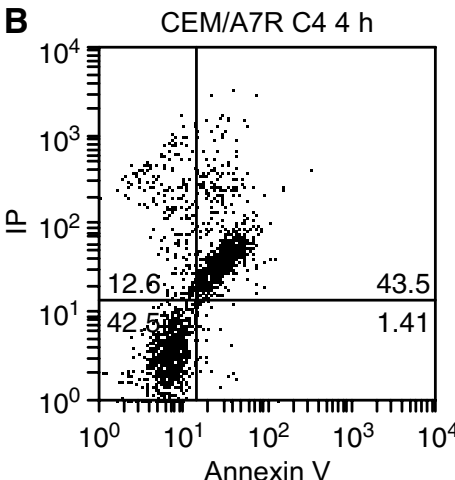

E

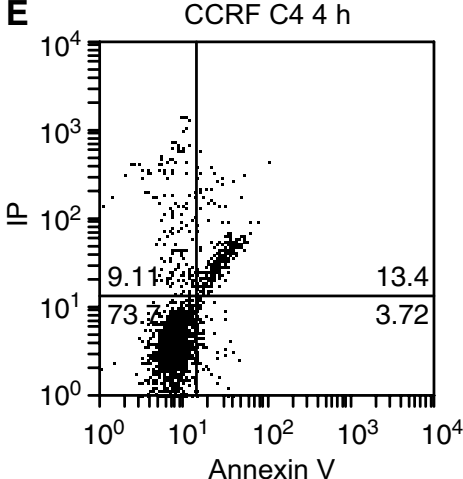

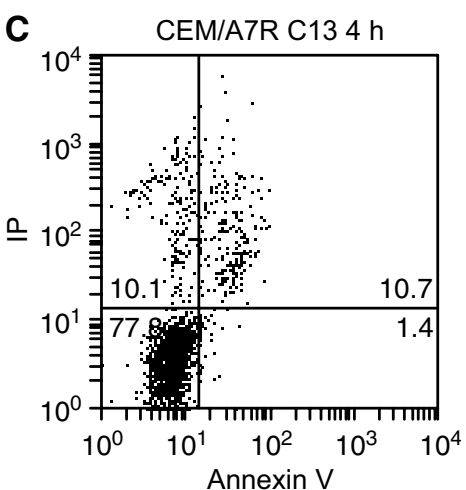

$\mathbf{F}$

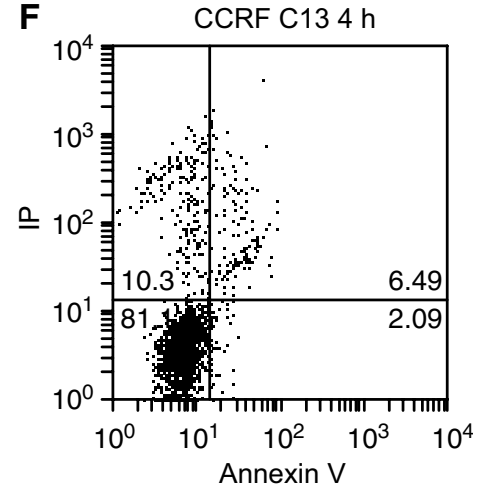

Figure 3 The percentage of dual staining of CEM/A7R and CCRF-CEM tested by flow cytometry using Annexin $V$ and PI after treatment with control Mab BCP7 (anti-MUCl) $(\mathbf{A}$ and $\mathbf{D})$ or $25 \mu \mathrm{g} \mathrm{ml}^{-1}$ of anti-Cripto Mab C4 (B and $\left.\mathbf{E}\right), \mathrm{Cl} 3$ (C and $\mathbf{F}$ ) for $4 \mathrm{~h}$

A

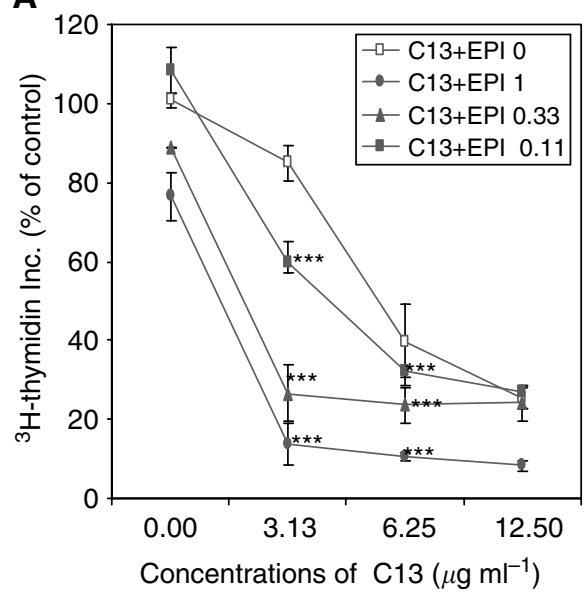

B

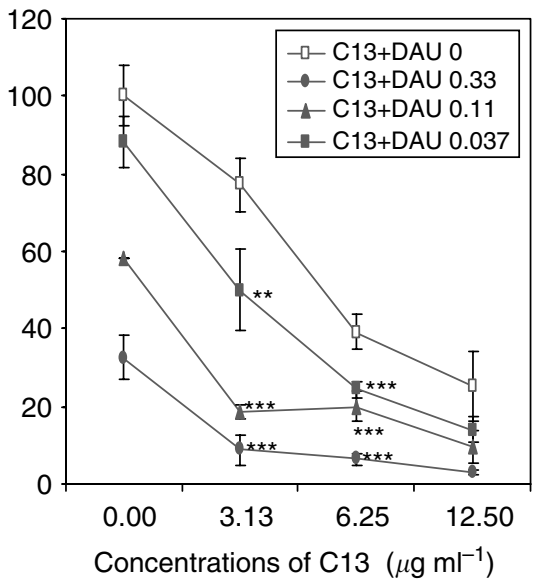

C

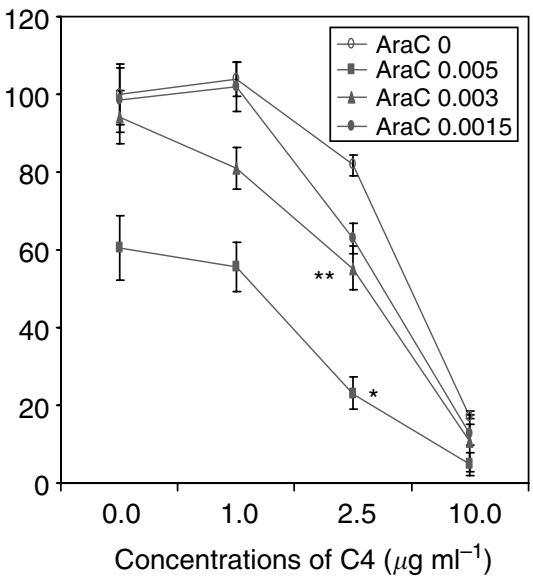

Figure 4 Inhibition of CEM/A7R cells by combined use of anti-Cripto Mab CI 3 with different concentrations of EPI at 0.11 to I $\mu \mathrm{g} \mathrm{ml}{ }^{-1}(\mathbf{A})$, DAU at $0.04-0.33 \mu \mathrm{g} \mathrm{ml}^{-1}$ (B) or C4 at various concentrations with Arac at $0.00 \mathrm{I} 5,0.003$ and $0.005 \mu \mathrm{g} \mathrm{ml} \mathrm{I}^{-1}(\mathbf{C})$ after $48 \mathrm{~h}$ incubation as measured by percentage of control in $\left[{ }^{3} \mathrm{H}\right]$ thymidine incorporation. Points are means of triplicate experiments. Error bars represent s.d. in triplicate experiments. The interactions of various concentrations of $\mathrm{Cl} 3$ with $\mathrm{EPI}, \mathrm{DAU}$ or $\mathrm{C} 4$ with AraC were subjected to two-way ANOVA. The $P$-values were marked as $* P<0.05$, $* * *<<0.01$, ***** $P<0.001$.

of Phospho-Akt at Ser473 has been demonstrated in Western blot analysis of CEM/A7R cells after $3 \mathrm{~h}$ incubation with $10 \mu \mathrm{g} \mathrm{ml}^{-1} \mathrm{C} 4$ or $0.02 \mu \mathrm{g} \mathrm{ml}^{-1}$ AraC, respectively (Figure $6 \mathrm{~B}$ ). The most effective inhibition of phospho-Akt was observed by incubation of CEM/ A7R with $10 \mu \mathrm{g} \mathrm{ml}^{-1} \mathrm{C} 4$ and $0.02 \mu \mathrm{g} \mathrm{ml}^{-1}$ AraC (Figure 6B). No changes in the levels of P44/42 (MAPK) or p38 were shown after treatment of the cells with $\mathrm{C} 4$ or AraC for $3 \mathrm{~h}$ (data not shown). The expression of Cripto was unchanged before and after treatment (Figure 6B).

\section{Caspase-9 cleavage}

Caspase 9 is an initiator for caspase. Cleaved caspase 9 is an activated form of caspase 9 and further processes other caspases, including caspase 3 and caspase 7, which amplify the cascade leading to apoptosis. c-Jun $\mathrm{N}$-terminal kinase is required for the stress-induced apoptosis mediated by mitochondrial/caspase-9 pathway (Tournier et al, 2000). Akt phosphorylates caspase-9 and inhibits caspase-9 protease. As shown in Figure 6A and B, JNK 


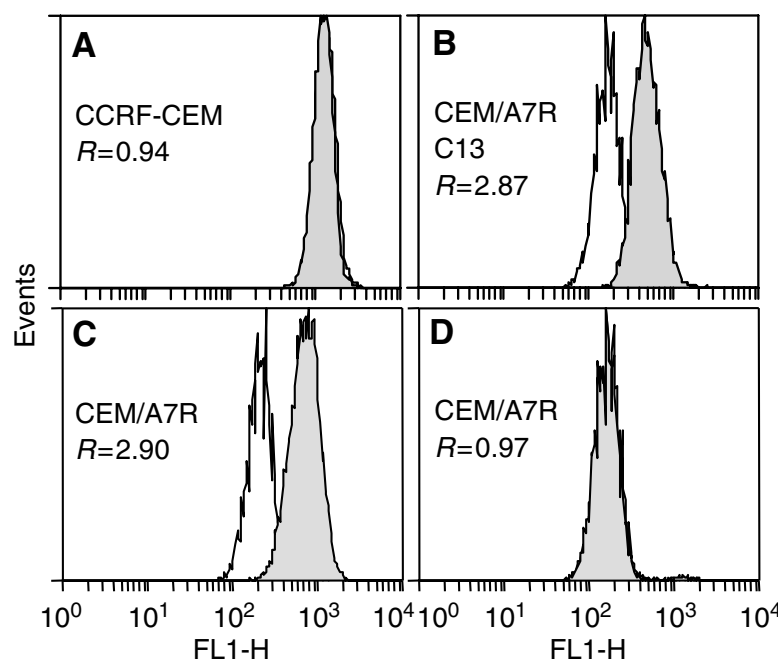

Fluorescence intensity

\section{E}

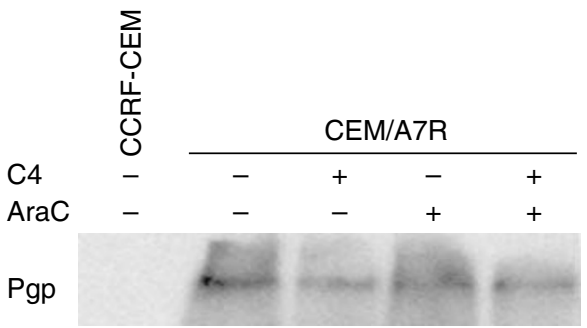

Figure 5 P-glycoprotein function and expression affected by anti-Cripto Mab in CCRF-CEM and CEM-A7R tested by flow cytometry and Western blot. (A and $\mathbf{C}$ ) Flow cytometry analysis of Rh 123 accumulation in the absence (open histogram) or presence of $10 \mu \mathrm{M} \vee p$ (solid histogram). (B) Rh 123 accumulation in the CEM/A7R cells following $3 \mathrm{~h}$ treatment with $25 \mu \mathrm{g} \mathrm{ml}^{-1} \mathrm{Cl} 3$ in the absence (open histogram) or presence of $10 \mu \mathrm{M} \mathrm{Vp}$ (solid histogram) or in the absence (open histogram) or presence of $25 \mu \mathrm{g} \mathrm{ml} l^{-1} \mathrm{Cl} 3$ (solid histogram) (D). P-glycoprotein function is expressed as the ratio of MCF in the presence or absence of $\mathrm{Vp}$ or $\mathrm{Cl} 3$ as described in the 'Materials and Methods'. P-glycoprotein levels were expressed as the ratio $(R)$ of the MCF. (E) Western blot analysis of Pgp expression detected by Mab to human Pgp in the CEM/A7R cells following $6 \mathrm{~h}$ treatment with $10 \mu \mathrm{g} \mathrm{ml}^{-1} \mathrm{C} 4,0.02 \mu \mathrm{g} \mathrm{ml}^{-1}$ AraC and combined use of the two reagents.

activation and Akt inhibition by $\mathrm{C} 4$ and $\mathrm{AraC}$ were associated with the appearance of cleaved caspase-9 at Asp330 (37 kDa). The most enhanced induction of cleaved caspase- 9 was induced by combined use of $\mathrm{C} 4$ and AraC (Figure 6B). This may explain the synergistic effect of anti-Cripto Mab to sensitise MDR CEM/A7R cells to AraC.

\section{Bad, Bcl-2 as apoptosis targets of anti-Cripto Mab}

Bad is a proapoptotic member of the Bcl-2 family that is capable of forming heterodimers with $\mathrm{Bcl}-2$ or $\mathrm{Bcl}-\mathrm{xL}$, and antagonises their antiapoptotic activity leading to cell death. Phosphorylation of Bad at Ser 136 by Akt or at Ser 112 through Ras/Raf/MAPK cascades resulted in the binding of $\mathrm{Bad}$ to 14-3-3 proteins, and inhibition of $\mathrm{Bad}$ binding to Bcl-2, Bcl-xL in promotion of cell survival (Zha et al, 1996). Thus, only dephosphorylation of $\mathrm{Bad}$ is associated with apoptosis. In the CEM/A7R cells, we demonstrated that $\mathrm{C} 4$ at $10 \mu \mathrm{g} \mathrm{ml}^{-1}$ or $\mathrm{AraC}$ at $0.02 \mu \mathrm{g} \mathrm{ml}^{-1}$ dramatically decreased phosphorylation of Bad at Ser136, but not at Ser112. $\mathrm{C} 4$ and AraC also significantly inhibited phosphorylation of Bcl-2 at Ser70, which was associated with cell survival in CEM/A7R. Treatment of CEM/A7R cells with combined use of $\mathrm{C} 4$ and AraC

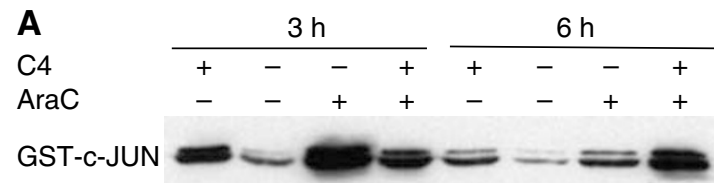

B

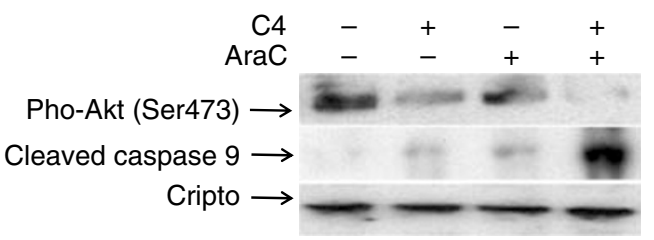

C

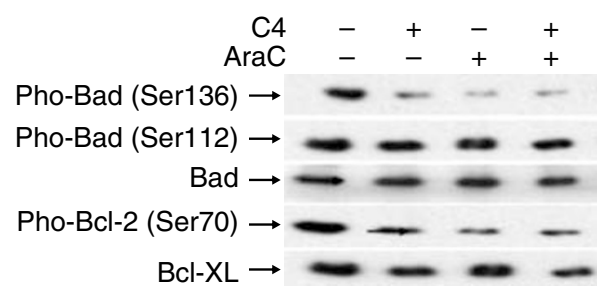

Figure 6 Western blot showing signalling molecules mediated by $\mathrm{C} 4$ AraC and combination of the two reagents in the CEM/A7R cells. (A) Activation of JNK/SAPK examined by JNK kinase assay and blotted by antiphosphor-c-Jun Mab in CEM/A7R cells treated with $10 \mu \mathrm{gml} \mathrm{m}^{-1} \mathrm{C} 4$ and $0.02 \mu \mathrm{g} \mathrm{ml}^{-1}$ AraC or combination for 3 or $6 \mathrm{~h}$. (B) Western blot analysis of phospho-Akt at Ser473 and cleavage of caspase 9 at Asp330 compared to the level of expression of Cripto and (C) Western blot analysis of phosphor-Bad at Serl36, Serl 12, total Bad protein, phosphor-Bcl-2 at Ser70, Bcl-XL in the same cell lysates.

further decreased phosphorylation of Bad at Ser136, Bcl-2 at Ser70 and slightly decreased Bcl-xL. However, total Bad protein was not affected by any treatment (Figure 6C).

\section{DISCUSSION}

Multidrug resistance related protein 1 (MDR1) related multipledrug resistance remains a major impediment undermining successful cancer treatment. Despite the recent developments of understanding the mechanisms, there is no effective method to treat relapsed cancer, which has developed MDR after failure of chemotherapy. Many studies focus on overcoming MDR through modulation of Pgp function. These include Pgp modulators Vp, CyA, PSC833, and recently developed anti-CD19 (Ghetie et al, 1999), anti-CD20 Mab (Demidem et al, 1997) and anti-Pgp Mab (Smyth et al, 1998). In addition to inhibition of Pgp function as drug efflux pump, these agents also showed inhibition of MDR1 expression during chemotherapy (Hu et al, 1996, 1999a) or interrupted interactions between Pgp and targeted antigen by antibodies leading to a dysfunction of Pgp (Ghetie et al, 2004). However, Pgp not only functions as a drug efflux pump, but also interrupts apoptotic pathways (Smyth et al, 1998; Johnstone et al, 1999). Here we demonstrated a distinguished strategy to overcome MDR in CEM/A7R cells by induction of cancer cell apoptosis signalling pathways using Mab to Cripto, a recently identified unique target for cancer therapy (Adkins et al, 2003; Xing et al, 2004; Hu and Xing, 2005). Cripto was found to be overexpressed in the CEM/A7R cells that acquired Pgp-mediated MDR by DOX treatment (Zalcberg et al, 1994). Activation of c-Src and MAPK/ PI3K/Akt pathways (Bianco et al, 2003) by Cripto involves in the cell proliferation and survival, resulting in an intervention of chemotherapeutics-induced apoptosis pathways and promotes MDR as demonstrated in several cancers (Grandage et al, 2005). 
Furthermore, activation of PI3K/Akt pathway has been suggested in controlling MDR mediated by Pgp and the MRP1, MRP2 (Abdul-Ghani et al, 2006). As MDR1 and Cripto are $\beta$-catenin target genes (Yamada et al, 2000; Morkel et al, 2003), coexpression of Pgp and Cripto in CEM/A7R cells could be simultaneously induced by intracellular accumulation of $\beta$-catenin during DOX selection, resulting in multiple defects in apoptosis pathways (Watts et al, 2001). We demonstrated that Mab to a 17-mer peptide within the EGF-like region of Cripto, $\mathrm{C} 4$ for example, induced massive induction of apoptosis in the CEM/A7R cells (Figure 3), which is three times higher than that in the Pgp-negative CCRFCEM cells, and correlated to the expression levels of Cripto (Figure $1 \mathrm{~A}$ and E). As a result, these anti-Cripto Mab inhibited Pgppositive CEM/A7R cell growth in vitro and established tumour growth in vivo (Figure 2).

Molecules known to predispose cells to apoptosis have shown to enhance sensitivity of tumour cells to a variety of chemotherapeutic agents (Fisher, 1994). We propose that anti-Cripto Mab could overcome MDR phenotype in Pgp expressing MDR cells by induction of apoptosis. As expected, anti-Cripto Mab overcame MDR, and combined use of Cripto Mab C13 with anthracyclines completely reversed resistance of MDR CEM/A7R cells to EPI and DAU (Figure 4A and B). These observations indicated that the residual of the drug-resistant tumour cells could be eradicated by the addition of low concentrations of antiCripto Mab to the originally unresponsive concentrations of chemotherapeutic Pgp substrates to prevent tumour cells from recurrence. Synergistic effect was also observed between interactions of anti-Cripto Mab and non-Pgp substrate AraC (Figure 4C). The findings may be clinically significant, because AraC has been used for many years in the treatment of AML, and the resistance to AraC remains a major obstacle in the effective treatment (Fernandez-Calotti et al, 2005). We also demonstrated that the reversal of Pgp-mediated MDR by anti-Cripto Mab in the Pgppositive CEM/A7R cells is irrelevant to Pgp function (Figure 5). These results indicated that MDR could be targeted by anti-Cripto Mab to bypass the Pgp through targeting a signal molecule to induce apoptosis in MDR tumour cells with overexpression of Cripto and Pgp. This strategy could be superior to targeting Pgp function as a low level of Pgp is expressed in many normal tissue cells such as liver, biliary tract, brain, kidney and intestines, which play roles in the excretion of toxins. Modulation of Pgp function caused decreased excretion of drugs and enhanced toxicities, such as nausea and vomiting, increased myelosuppression and hyperbilirubinemia (Szakacs et al, 2006). No obvious side effect was observed in the mouse model treated by anti-Cripto Mab. However, it should be investigated in future clinical trials using humanised Mab.

The molecular basis for anti-Cripto Mab in the induction of apoptosis and enhancing cytotoxicity of chemotherapeutics was examined on activation of JNK/SAPK and inhibition of Akt pathways. We found that JNK/SAPK pathway was activated by anti-Cripto Mab and AraC in the CEM/A7R cells. Combined use of $\mathrm{Mab}$ and AraC enhanced JNK activation by $6 \mathrm{~h}$ compared with them used alone (Figure 6A). Stress-activated JNK/SAPK apoptosis pathway is closely related to an alteration of dual function of Axin, a multidomain scaffold protein, which coordinates a variety of critical factors in determination of activation of JNK-apoptotic pathway or Wnt oncogenic signalling pathway (Zhang et al, 2001). In the CEM/A7R cells, PI3K/Akt pathway is intrinsically activated by Cripto (Ebert et al, 1999). Presumably, anti-Cripto Mab inhibits phosphorylation of Akt, a major molecule of PI3K/Akt pathway and interrupted Cripto/Akt/GSK- $3 \beta$ signalling pathways leading to destabilising $\beta$-catenin (Neo et al, 2000) and switching Axin to activate JNK apoptosis signalling instead of favouring in Wnt signalling activation (Zhang et al, 2001). Indeed, the level of Akt phosphorylation at Ser473 was reduced by the anti-Cripto Mab, indicating the Mab acted as an inhibitor of Akt activation
(Figure 6B). Targeting Akt pathway has been successful in attenuating chemotherapeutic resistance by small molecule inhibitor LY294002 (West et al, 2002). However, side effects and acquired resistance have limited in clinical use of these small molecular inhibitors. Moreover, many forms of cellular stress including chemotherapeutic cytotoxics can also upregulate PI3K/Akt signalling (West et al, 2002). Stress-induced activation of PI3K/Akt pathway is regarded as a protective compensatory mechanism for cells to escape chemotherapy-induced cell death (Martelli et al, 2006). A rapid upregulation of PI3K/Akt pathway has been observed in DAU-treated U937 human leukaemia cells (Plo et al, 1999). In contrast to DAU, AraC inhibited phosphorylation of Akt at Ser473, which was further abolished by combined use of $\mathrm{C} 4$ with AraC (Figure 6B). Therefore, the anti-Cripto Mab may be promising as a nonsmall molecule inhibitor in clinical use to inhibit activation of Akt signal pathway during chemotherapy.

Two principal pathways are involved in apoptosis: a pathway that is directly activated by death receptors and a pathway that involves mitochondria. Studies on the role of JNK in apoptotic signalling revealed that JNK is required for the stress induced apoptosis mediated by mitochondrial/caspase- 9 pathway (Tournier et al, 2000). Caspase-9, an important molecule to mediate mitochondrial pathway, is a cell death protease, which is phosphorylated and inactivated by Akt, and is cleaved by the cytochrome $c$ to initiate caspase cascade with requirement of JNK/ SAPK (Tournier et al, 2000). Our results showed that Cripto Mab and AraC-induced cleavage of caspase 9 at Asp 330, which were greatly amplified by the combined treatment of $\mathrm{C} 4$ and AraC, indicating the activation of mitochondria/caspase-9 apoptosis pathway is associated with a synergistic increase in the induction of apoptosis (Figures $4 \mathrm{C}$ and $6 \mathrm{~B}$ ). The combination of $\mathrm{C} 4$ and $\mathrm{AraC}$ had greater effects on JNK/SAPK activation and inhibition of Akt phosphorylation that correlates a synergistic increase in the induction of cleaved levels of casepase 9 (Figure 6A and B).

The mitochondria apoptosis pathway is primarily regulated by Bcl-2 family proteins consisting of anti-apoptotic Bcl-2 and $\mathrm{Bcl}-\mathrm{xL}$ and proapoptotic members Bad and Bax (Petros et al, 2004). Bad forms a heterodimer with the anti-apoptotic proteins Bcl-2 or Bcl-xL and thereby prevents them from exerting their antiapoptotic function. Several signalling pathways influence cell death through their effects on the phosphorylation of Bad at various sites (Downward, 1999). Akt phosphorylates Bad at Ser136, and promotes the association of Bad with 14-3-3 proteins in the cytosol and inactivates Bad pro-apoptotic function (Datta et al, 1997). Only the nonphosphorylated Bad heterodimerised with $\mathrm{Bcl}-\mathrm{xL}$ at mitochondria membrane sites to promote cell death. c-Jun N-terminal kinase/stress-activated protein kinase phosphorylated Bcl-2 at Ser70 in vitro and in vivo. Phosphorylation of Bcl-2 at Ser70 inhibits the antiapoptotic function of Bcl-2 (Yamamoto et al, 1999). Anti-Cripto Mab, AraC dramatically decrease phosphorylation of Bad at Ser136 and phosphorylation of Bcl-2 at Ser70 in the CEM/A7R cells, and had little effect on phosphorylation of Bad at Ser112, total level of Bad and Bcl-xL. The combined use of Mab and AraC induced further decrease of phosphorylation of Bad at Ser136 and Bcl-2 at Ser70 in the CEM/ A7R cells (Figure $6 \mathrm{C}$ ). The data demonstrate that a mitochondrial cell death pathway induced by anti-Cripto Mab is involved in the inhibition of cell growth and overcoming drug resistance in the MDR CEM/A7R.

\section{ACKNOWLEDGEMENTS}

We gratefully acknowledge the supports from the Association of International Cancer Research, UK (03-121); CASS Foundation, Australia (SM/04/374) and National Breast Cancer Foundation, Australia. 


\section{REFERENCES}

Abd El-Ghaffar HA, Aladle DA, Farahat SE, Abd El-Hady N (2006) Pglycoprotein (P-170) expression in acute leukemias. Hematology 11: $35-41$

Abdul-Ghani R, Serra V, Gyorffy B, Jurchott K, Solf A, Dietel M, Schafer R (2006) The PI3 K inhibitor LY294002 blocks drug export from resistant colon carcinoma cells overexpressing MRP1. Oncogene 25: 1743-1752

Adkins HB, Bianco C, Schiffer SG, Rayhorn P, Zafari M, Cheung AE, Orozco O, Olson D, De Luca A, Chen LL, Miatkowski K, Benjamin C, Normanno N, Williams KP, Jarpe M, LePage D, Salomon D, Sanicola M (2003) Antibody blockade of the Cripto CFC domain suppresses tumor cell growth in vivo. J Clin Invest 112: 575-587

Bianco C, Strizzi L, Rehman A, Normanno N, Wechselberger C, Sun Y, Khan N, Hirota M, Adkins H, Williams K, Margolis RU, Sanicola M, Salomon DS (2003) A Nodal- and ALK4-independent signaling pathway activated by Cripto-1 through Glypican-1 and c-Src. Cancer Res 63: $1192-1197$

Biscardi M, Teodori E, Caporale R, Budriesi R, Balestri F, Scappini B, Gavazzi S, Grossi A (2006) Multidrug reverting activity toward leukemia cells in a group of new verapamil analogues with low cardiovascular activity. Leuk Res 30: 1-8

Ciccodicola A, Dono R, Obici S, Simeone A, Zollo M, Persico MG (1989) Molecular characterization of a gene of the 'EGF family' expressed in undifferentiated human NTERA2 teratocarcinoma cells. EMBO $J$ 8: $1987-1991$

Clark AS, West K, Streicher S, Dennis PA (2002) Constitutive and inducible Akt activity promotes resistance to chemotherapy, trastuzumab, or tamoxifen in breast cancer cells. Mol Cancer Ther 1: 707-717

Datta SR, Dudek H, Tao X, Masters S, Fu H, Gotoh Y, Greenberg ME (1997) Akt phosphorylation of BAD couples survival signals to the cell-intrinsic death machinery. Cell 91: 231-241

Davis RJ (2000) Signal transduction by the JNK group of MAP kinases. Cell 103: $239-252$

Demidem A, Lam T, Alas S, Hariharan K, Hanna N, Bonavida B (1997) Chimeric anti-CD20 (IDEC-C2B8) monoclonal antibody sensitizes a $B$ cell lymphoma cell line to cell killing by cytotoxic drugs. Cancer Biother Radiopharm 12: $177-186$

Downward J (1999) How BAD phosphorylation is good for survival. Nat Cell Biol 1: E33-E35

Ebert AD, Wechselberger C, Frank S, Wallace-Jones B, Seno M, MartinezLacaci I, Bianco C, De Santis M, Weitzel HK, Salomon DS (1999) Cripto-1 induces phosphatidylinositol 3'-kinase-dependent phosphorylation of AKT and glycogen synthase kinase 3 beta in human cervical carcinoma cells. Cancer Res 59: 4502-4505

Fernandez-Calotti P, Jordheim LP, Giordano M, Dumontet C, Galmarini CM (2005) Substrate cycles and drug resistance to 1-beta-D-arabinofuranosylcytosine (araC). Leuk Lymphoma 46: 335-346

Fisher DE (1994) Apoptosis in cancer therapy: crossing the threshold. Cell 78: $539-542$

Foley GE, Lazarus H, Farber S, Uzman BG, Boone BA, McCarthy RE (1965) Continuous culture of human lymphoblasts from peripheral blood of a child with acute leukemia. Cancer 18: $522-529$

Ghetie MA, Ghetie V, Vitetta ES (1999) Anti-CD19 antibodies inhibit the function of the P-gp pump in multidrug-resistant B lymphoma cells. Clin Cancer Res 5: 3920 - 3927

Ghetie MA, Marches R, Kufert S, Vitetta ES (2004) An anti-CD19 antibody inhibits the interaction between P-glycoprotein (P-gp) and CD19, causes $\mathrm{P}$-gp to translocate out of lipid rafts, and chemosensitizes a multidrugresistant (MDR) lymphoma cell line. Blood 104: 178-183

Grandage VL, Gale RE, Linch DC, Khwaja A (2005) PI3-kinase/Akt is constitutively active in primary acute myeloid leukaemia cells and regulates survival and chemoresistance via NF-kappaB, Mapkinase and p53 pathways. Leukemia 19: 586-594

Hayes JD, Wolf CR (1990) Molecular mechanisms of drug resistance. Biochem J 272: $281-295$

Hu XF, Xing PX (2005) Cripto as a target for cancer immunotherapy. Expert Opin Ther Targets 9: 383-394

Hu XF, Martin TJ, Bell DR, de Luise M, Zalcberg JR (1990) Combined use of cyclosporin $\mathrm{A}$ and verapamil in modulating multidrug resistance in human leukemia cell lines. Cancer Res 50: 2953-2957

Hu XF, Slater A, Kantharidis P, Rischin D, Juneja S, Rossi R, Lee G, Parkin JD, Zalcberg JR (1999a) Altered multidrug resistance phenotype caused by anthracycline analogues and cytosine arabinoside in myeloid leukemia. Blood 93: 4086-4095
Hu XF, Slater A, Rischin D, Kantharidis P, Parkin JD, Zalcberg J (1999b) Induction of MDR1 gene expression by anthracycline analogues in a human drug resistant leukaemia cell line. Br J Cancer 79: 831 -837

Hu XF, Slater A, Wall DM, Kantharidis P, Parkin JD, Cowman A, Zalcberg JR (1995) Rapid up-regulation of mdrl expression by anthracyclines in a classical multidrug-resistant cell line. Br J Cancer 71: 931-936

Hu XF, Slater A, Wall DM, Parkin JD, Kantharidis P, Zalcberg JR (1996) Cyclosporin A and PSC 833 prevent up-regulation of MDR1 expression by anthracyclines in a human multidrug-resistant cell line. Clin Cancer Res 2: $713-720$

Johnstone RW, Cretney E, Smyth MJ (1999) P-glycoprotein protects leukemia cells against caspase-dependent, but not caspase-independent, cell death. Blood 93: 1075-1085

Kannan S, De Santis M, Lohmeyer M, Riese II DJ, Smith GH, Hynes N, Seno M, Brandt R, Bianco C, Persico G, Kenney N, Normanno N, MartinezLacaci I, Ciardiello F, Stern DF, Gullick WJ, Salomon DS (1997) Cripto enhances the tyrosine phosphorylation of Shc and activates mitogenactivated protein kinase (MAPK) in mammary epithelial cells. $J$ Biol Chem 272: $3330-3335$

Lee Jr JT, Steelman LS, McCubrey JA (2004) Phosphatidylinositol 3'-kinase activation leads to multidrug resistance protein-1 expression and subsequent chemoresistance in advanced prostate cancer cells. Cancer Res 64: $8397-8404$

Martelli AM, Nyakern M, Tabellini G, Bortul R, Tazzari PL, Evangelisti C, Cocco L (2006) Phosphoinositide 3-kinase/Akt signaling pathway and its therapeutical implications for human acute myeloid leukemia. Leukemia 20: $911-928$

Minn AJ, Rudin CM, Boise LH, Thompson CB (1995) Expression of bcl-xL can confer a multidrug resistance phenotype. Blood 86: 1903-1910

Morkel M, Huelsken J, Wakamiya M, Ding J, van de Wetering M, Clevers $H$, Taketo MM, Behringer RR, Shen MM, Birchmeier W (2003) Beta-catenin regulates Cripto- and Wnt3-dependent gene expression programs in mouse axis and mesoderm formation. Development 130: 6283-6294

Neo SY, Zhang Y, Yaw LP, Li P, Lin SC (2000) Axin-induced apoptosis depends on the extent of its JNK activation and its ability to down-regulate beta-catenin levels. Biochem Biophys Res Commun 272: $144-150$

Normanno N, De Luca A, Bianco C, Maiello MR, Carriero MV, Rehman A, Wechselberger C, Arra C, Strizzi L, Sanicola M, Salomon DS (2004) Cripto-1 overexpression leads to enhanced invasiveness and resistance to anoikis in human MCF-7 breast cancer cells. J Cell Physiol 198: 31-39

Petros AM, Olejniczak ET, Fesik SW (2004) Structural biology of the Bcl-2 family of proteins. Biochim Biophys Acta 1644: 83-94

Plo I, Bettaieb A, Payrastre B, Mansat-De Mas V, Bordier C, Rousse A, Kowalski-Chauvel A, Laurent G, Lautier D (1999) The phosphoinositide 3-kinase/Akt pathway is activated by daunorubicin in human acute myeloid leukemia cell lines. FEBS Lett 452: 150-154

Saloman DS, Bianco C, Ebert AD, Khan NI, De Santis M, Normanno N, Wechselberger C, Seno M, Williams K, Sanicola M, Foley S, Gullick WJ, Persico G (2000) The EGF-CFC family: novel epidermal growth factorrelated proteins in development and cancer. Endocr Relat Cancer 7: 199 226

Seidensticker MJ, Behrens J (2000) Biochemical interactions in the wnt pathway. Biochim Biophys Acta 1495: 168-182

Slinker BK (1998) The statistics of synergism. J Mol Cell Cardiol 30: 723 731

Smyth MJ, Krasovskis E, Sutton VR, Johnstone RW (1998) The drug efflux protein, P-glycoprotein, additionally protects drug-resistant tumor cells from multiple forms of caspase-dependent apoptosis. Proc Natl Acad Sci USA 95: 7024-7029

Szakacs G, Paterson JK, Ludwig JA, Booth-Genthe C, Gottesman MM (2006) Targeting multidrug resistance in cancer. Nat Rev Drug Discov 5: $219-$ 234

Tournier C, Hess P, Yang DD, Xu J, Turner TK, Nimnual A, Bar-Sagi D, Jones SN, Flavell RA, Davis RJ (2000) Requirement of JNK for stressinduced activation of the cytochrome $c$-mediated death pathway. Science 288: $870-874$

Vermes I, Haanen C, Steffens-Nakken H, Reutelingsperger C (1995) A novel assay for apoptosis. Flow cytometric detection of phosphatidylserine expression on early apoptotic cells using fluorescein labelled Annexin V. J Immunol Methods 184: 39-51

Watts GS, Futscher BW, Isett R, Gleason-Guzman M, Kunkel MW, Salmon SE (2001) cDNA microarray analysis of multidrug resistance: 
doxorubicin selection produces multiple defects in apoptosis signaling pathways. J Pharmacol Exp Ther 299: 434-441

West KA, Castillo SS, Dennis PA (2002) Activation of the PI3K/Akt pathway and chemotherapeutic resistance. Drug Resist Updat 5: 234-248

Xia Z, Dickens M, Raingeaud J, Davis RJ, Greenberg ME (1995) Opposing effects of ERK and JNK-p38 MAP kinases on apoptosis. Science 270: $1326-1331$

Xing PX, Hu XF, Pietersz GA, Hosick HL, McKenzie IF (2004) Cripto: a novel target for antibody-based cancer immunotherapy. Cancer Res 64: $4018-4023$

Yamada T, Takaoka AS, Naishiro Y, Hayashi R, Maruyama K, Maesawa C, Ochiai A, Hirohashi S (2000) Transactivation of the multidrug resistance 1 gene by T-cell factor 4/beta-catenin complex in early colorectal carcinogenesis. Cancer Res 60: $4761-4766$

Yamada Y, Yoshimi N, Sugie S, Suzui M, Matsunaga K, Kawabata K, Hara A, Mori H (1999) Beta-catenin (Ctnnb1) gene mutations in diethyl- nitrosamine (DEN)-induced liver tumors in male F344 rats. Ipn J Cancer Res 90: $824-828$

Yamamoto K, Ichijo H, Korsmeyer SJ (1999) BCL-2 is phosphorylated and inactivated by an ASK1/Jun N-terminal protein kinase pathway normally activated at G(2)/M. Mol Cell Biol 19: 8469-8478

Zalcberg JR, Hu XF, Wall DM, Mirski S, Cole S, Nadalin G, De Luise M, Parkin JD, Vrazas V, Campbell L, Kantharidis P (1994) Cellular and karyotypic characterization of two doxorubicin resistant cell lines isolated from the same parental human leukemia cell line. Int J Cancer 57: $522-528$

Zha J, Harada H, Yang E, Jockel J, Korsmeyer SJ (1996) Serine phosphorylation of death agonist BAD in response to survival factor results in binding to 14-3-3 not BCL-X(L). Cell 87: 619-628

Zhang Y, Qiu WJ, Liu DX, Neo SY, He X, Lin SC (2001) Differential molecular assemblies underlie the dual function of Axin in modulating the WNT and JNK pathways. J Biol Chem 276: 32152-32159 